\title{
Promotion Effects in the Oxidation of CO over Zeolite-Supported Pt Nanoparticles
}

\author{
Tom Visser ${ }^{\dagger}{ }^{\text {T. }}$. Alexander Nijhuis,${ }^{\dagger}$ Ad M. J. van der Eerden, ${ }^{\dagger}$ Karin Jenken, ${ }^{\dagger}$ Yaying Ji, ${ }^{\dagger}$ \\ Wim Bras, ${ }^{\ddagger}$ Sergei Nikitenko, ${ }^{\ddagger}$ Yasuo Ikeda, ${ }^{\S}$ Muriel Lepage, ${ }^{\S}$ and Bert M. Weckhuysen*, ${ }^{\ddagger}$ \\ Department of Inorganic Chemistry and Catalysis, Debye Institute, Utrecht University, Sorbonnelaan 16, \\ 3584 CA Utrecht, The Netherlands, DUBBLE CRG, ESRF, BP 220, 38043 Grenoble Cedex 9, France, and \\ Material Engineering Division, Toyota Motor Engineering \& Manufacturing Europe Technical Centre, \\ Hoge Wei 33B, B-1930 Zaventem, Belgium
}

Received: November 16, 2004; In Final Form: December 23, 2004

\begin{abstract}
Well-defined Pt-nanoparticles with an average diameter of $1 \mathrm{~nm}$ supported on a series of zeolite $\mathrm{Y}$ samples containing different monovalent $\left(\mathrm{H}^{+}, \mathrm{Na}^{+}, \mathrm{K}^{+}, \mathrm{Rb}^{+}\right.$, and $\left.\mathrm{Cs}^{+}\right)$and divalent $\left(\mathrm{Mg}^{2+}, \mathrm{Ca}^{2+}, \mathrm{Sr}^{2+}\right.$, and $\left.\mathrm{Ba}^{2+}\right)$ cations have been used as model systems to investigate the effect of promotor elements in the oxidation of $\mathrm{CO}$ in excess oxygen. Time-resolved infrared spectroscopy measurements allowed us to study the temperatureprogrammed desorption of $\mathrm{CO}$ from supported Pt nanoparticles to monitor the electronic changes in the local environment of adsorbed $\mathrm{CO}$. It was found that the red shift of the linear Pt-coordinated $\mathrm{C} \equiv \mathrm{O}$ vibration compared to that of gas-phase $\mathrm{CO}$ increases with an increasing cation radius-to-charge ratio. In addition, a systematic shift from linear $(\mathrm{L})$ to bridge $(\mathrm{B})$ bonded $\mathrm{C} \equiv \mathrm{O}$ was observed for decreasing Lewis acidity, as expressed by the Kamlet-Taft parameter $\alpha$. A decreasing $\alpha$ results in an increasing electron charge on the framework oxygen atoms and therefore an increasing electron charge on the supported Pt nanoparticles. This observation was confirmed with X-ray absorption spectroscopy, and the intensity of the experimental Pt atomic XAFS correlates with the Lewis acidity of the cation introduced. Furthermore, it was found that the CO coverage increases with increasing electron density on the Pt nanoparticles. This increasing electron density was found to result in an increased $\mathrm{CO}$ oxidation activity; i.e., the $T_{50 \%}$ for $\mathrm{CO}$ oxidation decreases with decreasing $\alpha$. In other words, basic promotors facilitate the chemisorption of $\mathrm{CO}$ on the Pt particles. The most promoted CO oxidation catalyst is a $\mathrm{Pt} / \mathrm{K}-\mathrm{Y}$ sample, which has a $T_{50 \%}$ of $390 \mathrm{~K}$ and a L:B intensity ratio of 2.7. The obtained results provide guidelines to design improved $\mathrm{CO}$ oxidation catalysts.
\end{abstract}

\section{Introduction}

Understanding the effect of a support oxide on the properties of noble metal particles is a challenging subject because it opens a way toward modeling and tuning of the catalytic properties by a deliberate choice of the support. The catalytic activity of supported Pt nanoparticles is well-known to be sensitive to the support composition, acid-base properties, and pore curvature, ${ }^{1-3}$ but despite many studies that have been undertaken to elucidate the exact nature of the relationship, many questions still remain open.

A very useful, but often underestimated, technique is infrared spectroscopy (IR) because the IR spectrum of chemisorbed carbon monoxide (CO) can be regarded as a sensitive and local probe of the electronic properties of supported Pt nanoparticles. ${ }^{4,5}$ Its application is based on the fact that differences in electronic state are reflected in changes in the vibrational characteristics of the $\mathrm{Pt}-\mathrm{CO}$ adduct. The result is a red shift of the CO stretching frequency compared to that of the gas phase and the appearance of two principal IR bands: one in the region $2100-1900 \mathrm{~cm}^{-1}$, which is assigned to CO that is coordinated linear to Pt, and a bridged bonded one between 1900 and 1700 $\mathrm{cm}^{-1}$, which is attributed to 2-, 3-, or even 4-fold-coordinated CO. Next to the stretching frequency, the intensity ratio of the

\footnotetext{
* To whom correspondence should be addressed. E-mail b.m.weckhuysen@chem.uu.nl.

$\dagger$ Utrecht University.

$\doteqdot$ DUBBLE CRG.

$\S$ Toyota Motor Engineering \& Manufacturing Europe Technical Centre.
}

linear and bridged bonded bands ( $\mathrm{L}: \mathrm{B}$ ratio) can be used as a measure for the electronic state of the Pt nanoparticles. ${ }^{6}$ It has been found that Pt nanoclusters on basic supports are relatively more electron-rich than on acidic supports, which is reflected by an increased red shift of the $\mathrm{CO}$ stretching frequency and a decreased L:B ratio. ${ }^{6-8}$ Another attractive feature of the IR technique is that it can be used to perform real-time temperature programmed desorption (TPD) studies to obtain direct information on changes in the $\mathrm{Pt}-\mathrm{C}(\mathrm{O})$ bond strength. Surprisingly, only a few IR thermal desorption studies of $\mathrm{Pt}-\mathrm{CO}$ systems have been reported in the literature, mainly dealing with stepped single Pt crystals. ${ }^{4,9-14}$ To our best knowledge, IR-CO-TPD studies on supported Pt catalysts have only been reported by Barth et al. ${ }^{4,13}$ and Gandao et al. ${ }^{14}$ The former group compared the $\mathrm{CO}$ desorption process from $\mathrm{Pt} / \mathrm{SiO}_{2}$ and $\mathrm{Pt} / \mathrm{Al}_{2} \mathrm{O}_{3}$ upon heating and cooling, whereas the latter team used the technique to determine the presence of three types of $\mathrm{Pt}$ bonded $\mathrm{CO}$ on $\mathrm{Pt} / \mathrm{Mg}(\mathrm{Al}) \mathrm{O}$ catalysts.

It is clear that systematic studies on well-defined Pt nanoparticles supported on a wide range of porous oxides are lacking in the literature, preventing the generalization of some of the above-mentioned conclusions. As a consequence, the aim of the present research is to investigate the effect of monovalent $\left(\mathrm{H}^{+}, \mathrm{Na}^{+}, \mathrm{K}^{+}, \mathrm{Rb}^{+}\right.$, and $\left.\mathrm{Cs}^{+}\right)$and divalent cations $\left(\mathrm{Mg}^{2+}, \mathrm{Ca}^{2+}\right.$, $\mathrm{Sr}^{2+}$, and $\mathrm{Ba}^{2+}$ ) on the electronic properties of $\mathrm{Pt}$ particles encaged in the supercages of zeolite $\mathrm{Y}$ by means of the IR$\mathrm{CO}-\mathrm{TPD}$ technique. The results will be discussed in relation to the corresponding $\mathrm{CO}$ oxidation activity and spectroscopic 
TABLE 1: Overview of the Supported Pt Catalysts under Study, Together with Some Physicochemical Properties As Determined with $\mathrm{N}_{2} / \mathrm{H}_{2}$ Chemisorption, X-ray Fluorescence, High-Resolution Transmission Electron Microscopy, and $\mathrm{NH}_{3}$ Temperature Programmed Desorption

\begin{tabular}{|c|c|c|c|c|c|c|}
\hline sample name & wt $\% \mathrm{Pt}$ & $\begin{array}{l}\text { Pt particle size }(\mathrm{nm}) \text { and their relative } \\
\text { abundance as determined with HRTEM }\end{array}$ & $\begin{array}{l}\text { surface area } \\
\left(\mathrm{m}^{2} / \mathrm{g}\right)\end{array}$ & $\begin{array}{c}\text { pore vol } \\
(\mathrm{mL} / \mathrm{g})\end{array}$ & $\begin{array}{c}\text { dispersion }(\%) \\
\text { as determined with } \\
\mathrm{H}_{2} \text { chemisorption }\end{array}$ & $\begin{array}{c}\mathrm{H}^{+}(\mathrm{mmol} / \mathrm{g}) \\
\text { as determined with } \\
\mathrm{NH}_{3} \mathrm{TPD}\end{array}$ \\
\hline $\mathrm{Pt} / \mathrm{H}-\mathrm{Y}$ & 1.2 & $\leq 1$ (exclusive) & 700 & 0.28 & 93 & 1.97 \\
\hline $\mathrm{Pt} / \mathrm{Na}-\mathrm{Y}$ & 1.0 & $\leq 1$ (exclusive) & 686 & 0.27 & 95 & 0.16 \\
\hline $\mathrm{Pt} / \mathrm{K}-\mathrm{Y}$ & 1.1 & $\leq 1$ (main fraction); $3 \mathrm{~nm}$ (traces) & 690 & 0.27 & 82 & 0.15 \\
\hline $\mathrm{Pt} / \mathrm{Rb}-\mathrm{Y}$ & 1.0 & $\leq 1$ (main fraction); $3 \mathrm{~nm}$ (traces) & 678 & 0.27 & 88 & 0.16 \\
\hline $\mathrm{Pt} / \mathrm{Cs}-\mathrm{Y}$ & 0.8 & $\leq 1$ (fraction); $5 \mathrm{~nm}$ (significant fraction) & 542 & 0.23 & 69 & 0.18 \\
\hline $\mathrm{Pt} / \mathrm{Mg}-\mathrm{Y}$ & 1.3 & $\leq 1$ (main fraction); $10 \mathrm{~nm}$ (traces) & 679 & 0.27 & 82 & 0.22 \\
\hline $\mathrm{Pt} / \mathrm{Ca}-\mathrm{Y}$ & 1.2 & $\leq 1$ (main fraction); $5 \mathrm{~nm}$ (traces) & 687 & 0.27 & 83 & 0.17 \\
\hline $\mathrm{Pt} / \mathrm{Sr}-\mathrm{Y}$ & 0.9 & $\leq 1$ (main fraction); $5 \mathrm{~nm}$ (traces) & 690 & 0.27 & 82 & 0.15 \\
\hline $\mathrm{Pt} / \mathrm{Ba}-\mathrm{Y}$ & 1.0 & $\leq 1$ (exclusive) & 696 & 0.27 & 92 & 0.18 \\
\hline
\end{tabular}

Pt atomic XAFS (AXAFS) data of these materials. It will be shown that an increasing electron charge on the supported $\mathrm{Pt}$ nanoparticles indirectly induced by alkaline and earth alkaline metal ions via the framework oxygen atoms promotes the $\mathrm{CO}$ oxidation activity due to an increased $\mathrm{CO}$ surface coverage. Furthermore, the systems under investigation can be envisaged as model systems for the $\mathrm{NO}_{x}$ storage-reduction catalysts (e.g., $\mathrm{Pt}-\mathrm{BaO} / \mathrm{Al}_{2} \mathrm{O}_{3}$ ) currently used in cars. The results of the present study show that $\mathrm{BaO}$ plays most likely a dual role because it acts as a $\mathrm{NO}_{x}$ trap but also promotes the $\mathrm{CO}$ oxidation activity of the supported Pt nanoparticles. The work therefore provides guidelines for the development of improved three-way exhaust catalytic converters.

\section{Experimental Section}

Prior to preparation and characterization, it should be emphasized that the $\mathrm{CO}$ stretching vibration of Pt-chemisorbed $\mathrm{CO}$ is not only sensitive to the support characteristics but also to a large number of experimental parameters. According to literature, the loading, dispersion, particle size, and coordination number of $\mathrm{Pt},{ }^{9,15-19}$ the reduction temperature, ${ }^{20,21}$ and $\mathrm{CO}$ exposure pressure ${ }^{22,23}$ can affect the observed IR data, whereas sample pretreatment, ${ }^{24} \mathrm{CO}$ exposure temperature, ${ }^{12} \mathrm{CO}$ adsorption, ${ }^{25}$ and $\mathrm{CO}$ interaction with support cations ${ }^{7,26}$ may play a role as well. To prevent erroneous assignments and conclusions, special attention has been paid to keep all experimental parameters and instrumental settings the same.

1. Catalyst Preparation. $\mathrm{H}-\mathrm{Y}$ (Si:Al ratio of 2.71) has been obtained from Linde, whereas the starting material for ion exchange was a $\mathrm{Na}-\mathrm{Y}$ ( $\mathrm{Si}: \mathrm{Al}$ ratio of 2.49 ) material from Ventron. The zeolite materials were put in their $\mathrm{Na}^{+}, \mathrm{K}^{+}, \mathrm{Rb}^{+}$, $\mathrm{Cs}^{+}, \mathrm{Mg}^{2+}, \mathrm{Ca}^{2+}, \mathrm{Sr}^{2+}$, and $\mathrm{Ba}^{2+}$ form by four successive ion exchanges for $12 \mathrm{~h}$ with an aqueous $1 \mathrm{M}$ solution of $\mathrm{NaCl}$ (Aldrich, p.a.), $\mathrm{KCl}$ (Aldrich, p.a.), $\mathrm{RbCl}$ (Merck, p.a.), $\mathrm{CsCl}$ (Merck, p.a.), $\mathrm{MgCl}_{2}$ (UCB, p.a.), $\mathrm{CaCl}_{2}$ (UCB, p.a.), $\mathrm{SrCl}_{2}$ (Aldrich, p.a.), and $\mathrm{BaCl}_{2}$ (Aldrich, p.a.), respectively. The samples were washed chlorine-free and dried in air at roomtemperature overnight. The crystallinity before and after ion exchange was confirmed by XRD and SEM techniques. Chemical analysis of the zeolite materials indicated that after four successive ion exchange steps the degree of exchange was above $98 \%$ for all materials under study. Details of the zeolite materials can also be found elsewhere. ${ }^{27}$ As will be shown, the zeolite materials, with the exception of $\mathrm{H}-\mathrm{Y}$, are almost free of Brönsted acid sites, ensuring that the ion exchange of the promoter cations does not introduce $\mathrm{H}^{+}$-sites in the catalyst materials.

Supported Pt particles (1 wt \%) were prepared via a dry impregnation step of the support materials with the appropriate aqueous solutions of $\mathrm{Pt}\left(\mathrm{NH}_{3}\right)_{4}\left(\mathrm{NO}_{3}\right)_{2}$. After impregnation and drying at $353 \mathrm{~K}$ in $\mathrm{N}_{2}$ (quality 4.0; Hoekloos) for $12 \mathrm{~h}$, calcination was carried out by drying in a high airflow $(30 \mathrm{~mL} /$ $\mathrm{min}$ ) for $12 \mathrm{~h}$ followed by increasing the temperature to $573 \mathrm{~K}$ at a heating rate of $0.2 \mathrm{~K} / \mathrm{min}$ to achieve complete removal of $\mathrm{NH}_{3}$ prior to reduction. Reduction was performed in pure $\mathrm{H}_{2}$ (quality 5.0; Hoekloos) with a flow of $10 \mathrm{~mL} / \mathrm{min}$ at $573 \mathrm{~K}$ for $2 \mathrm{~h}$. After reduction and flushing with $\mathrm{N}_{2}$ at room temperature, passivation was carried out by admitting a small amount of air $(10 \mathrm{~mL} / \mathrm{min})$ into the system to prevent aggregation of $\mathrm{Pt}$ particles. Table 1 summarizes the different supported Pt catalysts under study in this work.

2. Catalyst Characterization. X-ray fluorescence (XRF) was carried out on all samples to determine the Pt loadings using a Spectro X-lab 2000 instrument. $\mathrm{N}_{2}$ physisorption was performed at $77 \mathrm{~K}$ with a Micromeretics ASAP 2400 apparatus (quality 4.0; Hoekloos). Prior to these measurements, the samples were degassed for $24 \mathrm{~h}$ at $573 \mathrm{~K}$ in vacuum. Surface area, pore volume and pore size distribution were calculated with standard BET theory. Hydrogen chemisorption measurements were performed in a conventional static volume apparatus (Micromeretics ASAP 2010C). The samples were first dried under evacuation at $373 \mathrm{~K}$ overnight, then reduced in pure $\mathrm{H}_{2}$ at 573 $\mathrm{K}$ for $1 \mathrm{~h}$ (ramp: $5 \mathrm{~K} / \mathrm{min}$ ). The samples were cooled in $\mathrm{H}_{2}$ down to $523 \mathrm{~K}$ and evacuated at this temperature for $1 \mathrm{~h}$. Subsequently, the samples were cooled in a vacuum to room temperature and $\mathrm{H}_{2}$ adsorption isotherms were taken at $309 \mathrm{~K}$. At room temperature, the samples were evacuated and a second isotherm was recorded. The hydrogen chemisorption capacity was calculated at the difference between the two isotherms extrapolated to zero pressure. The Pt dispersions were calculated on the basis of the assumption that one hydrogen atom is adsorbed per platinum surface atom. The number of support protons was determined by temperature programmed desorption $\left(\mathrm{NH}_{3} \mathrm{TPD}\right)$ for catalysts containing only chemisorbed $\mathrm{NH}_{3}$. Approximately $1 \mathrm{~g}$ of catalyst was saturated in a flow of $5 \%$ $\mathrm{NH}_{3} / \mathrm{N}_{2}$ at room temperature. To remove physisorbed $\mathrm{NH}_{3}$, the catalyst was washed three times in $50 \mathrm{~mL}$ of $\mathrm{H}_{2} \mathrm{O}$ at $353 \mathrm{~K}$, filtered, and dried at $373 \mathrm{~K}$. The quantity of desorbed $\mathrm{NH}_{3}$ was determined by titration with a standard solution of $0.1 \mathrm{M} \mathrm{HCl}$. The number of protons was calculated on the basis of the assumption that one $\mathrm{NH}_{3}$ molecule was chemisorbed per acid site. High-resolution transmission electron microscopy (HRTEM) was done with a Philips CM 30 UT electron microscope equipped with a field emission gun as the source of Elecron operated at $300 \mathrm{kV}$. Samples were mounted on a microgrid carbon polymer supported on a copper grid by placing a few droplets of a suspension of ground sample in ethanol on the grid, followed by drying at ambient conditions. Extended X-ray absorption fine structure (EXAFS) measurements were carried out at Hasylab (Germany) at station $\times 1.1$ and at the ESRF 
(France) at CRG DUBBLE (BM26A). Both beamlines were equipped with a double crystal monochromator with Si111 crystals. Measurements were performed in transmission, and ion chambers were used for detection with a gas fill to absorb $20 \%$ in the first and $80 \%$ in the second ion chamber. Reduction of the higher harmonic radiation at Hasylab was established by detuning the second crystal to $50 \%$ of the maximum intensity, and at the DUBBLE station by using a vertically focusing mirror installed behind the monochromator. The samples were prepared by pressing 0.120 to $0.140 \mathrm{~g}$ powder to a self-supporting wafer. Next, the wafer was placed in a treatment cell. Prior to measurement, the sample was dried at $423 \mathrm{~K}$ for $30 \mathrm{~min}$ in a flow of dry $\mathrm{He}$ and then slowly heated to $573 \mathrm{~K}$ under a flow of $10 \% \mathrm{H}_{2}$ in $\mathrm{He}$ to reduce the passivated Pt. Next, the samples were measured at liquid $\mathrm{N}_{2}$ temperature. EXAFS data analysis was carried out with the XDAP program. ${ }^{28}$

IR measurements were performed on self-supported catalyst wafers that were pressed from 0.01 to $0.020 \mathrm{~g}$ of calcined and reduced sample material. A pressure of 3 bar was applied during $10 \mathrm{~s}$ to prevent destruction of the pore structure of the support. ${ }^{24}$ The wafer was placed in an IR transmission cell equipped with $\mathrm{CaF}_{2}$ windows as previously described. ${ }^{29}$ The cell was evacuated to $10^{-8}$ bar followed by drying of the wafer at $393 \mathrm{~K}$ overnight prior to reduction by a $10 \mathrm{~mL} / \mathrm{min}$ flow of $\mathrm{H}_{2}$ (quality 4.6 ; Hoekloos). During reduction the temperature was raised from $393 \mathrm{~K}$ with $3 \mathrm{~K} / \mathrm{min}$ to $573 \mathrm{~K}$ where it was maintained for $1 \mathrm{~h}$. Next the system was switched to vacuum and after $1 \mathrm{~h}$ at 573 $\mathrm{K}$, cooled to $323 \mathrm{~K}$ at a rate of $3 \mathrm{~K} / \mathrm{min}$ where it was maintained for $1 \mathrm{~h}$. We believe on the basis of the absence of a $\mathrm{Pt}-\mathrm{H}$ stretching vibration at around $2050 \mathrm{~cm}^{-1}$ in the Pt-loaded samples that this vacuum treatment removed all the hydrogen from the supported Pt nanoparticles. Next the system was switched to $10 \%$ CO (quality 4.7; Hoekloos) in He (quality 4.6; Hoekloos) at a starting pressure of 0.2 bar. After 30 min of static pressure, the system was reevacuated and after another $30 \mathrm{~min}$, temperature programmed desorption (TPD) was started by increasing the temperature from 323 to $573 \mathrm{~K}(3 \mathrm{~K} / \mathrm{min})$ where it was maintained for $30 \mathrm{~min}$. IR spectra were recorded on a Perkin-Elmer 2000 FTIR instrument with a data point resolution of $4 \mathrm{~cm}^{-1}$. For each spectrum 25 scans were coadded. As a background, the spectrum of the catalyst wafer was taken after drying, reduction and cooling to $323 \mathrm{~K}, 2$ min prior to $\mathrm{CO}$ exposure. During adsorption and TPD, time-resolved scanning was carried out by automatically acquiring spectral data every $2 \mathrm{~min}$, using Perkin-Elmer Time-Base software. To obtain spectra of the adsorbed $\mathrm{CO}$ during $\mathrm{CO}$ exposure, the gasphase spectrum of $\mathrm{CO}$ was subtracted from the spectrum that was taken prior to reevacuation of the cell. Intensity data were acquired by calculating the integrated area of baseline corrected spectra using the Perkin-Elmer Spectrum software. The reproducibility of all IR-TPD measurements was verified by carrying out the experiments in duplo in two ways: (1) by analyzing two different wafers from the same sample and (2) by repeating the exposure and desorption process to the same wafer without opening the IR cell.

3. Catalytic Testing. The Pt-catalysts were tested for the oxidation of $\mathrm{CO}$ in a 6-flow reactor setup, descibed in detail elsewhere. ${ }^{30}$ For this purpose, $20 \mathrm{mg}$ of each catalyst diluted with $200 \mathrm{mg}$ of $\mathrm{SiC}$ was loaded in the reactors. The reacting gas consists of $1000 \mathrm{ppm}$ of $\mathrm{CO}$ in an excess of $10 \%$ of $\mathrm{O}_{2}$. The flow rate was $250 \mathrm{~mL} / \mathrm{min}$ and the heating and cooling rates were $0.3 \mathrm{~K} / \mathrm{min}$. The catalysts were tested reversibly and $\mathrm{CO}$ and $\mathrm{CO}_{2}$ gas analysis was done with a nondispersive IR analyzer.
TABLE 2: EXAFS Fit Parameters of the Supported Pt Catalysts under Study, Together with the Corresponding AXAFS Intensities

\begin{tabular}{lccccrc}
\hline & & & $\begin{array}{c}\Delta \sigma^{2} \\
\left(\AA^{2}\right)\end{array}$ & $\begin{array}{c}R \\
(\AA)\end{array}$ & $\begin{array}{c}E_{0} \\
(\mathrm{eV})\end{array}$ & $\begin{array}{c}\text { AXAFS intensity } \\
\left(\times 10^{-2}\right)\end{array}$ \\
\hline $\mathrm{Pt} / \mathrm{H}-\mathrm{Y}$ & $\mathrm{Pt}$ & 5.4 & 3.4 & 2.74 & 1.9 & 2.20 \\
& $\mathrm{O}$ & 0.2 & 3.0 & 2.10 & -12.3 & \\
$\mathrm{Pt} / \mathrm{Na}-\mathrm{Y}$ & $\mathrm{Pt}$ & 5.7 & 4.6 & 2.73 & 2.5 & 1.06 \\
& $\mathrm{O}$ & 0.6 & 3.8 & 2.07 & -15.0 & \\
$\mathrm{Pt} / \mathrm{K}-\mathrm{Y}$ & $\mathrm{Pt}$ & 6.2 & 4.4 & 2.74 & 2.2 & 0.94 \\
& $\mathrm{O}$ & 0.2 & 3.4 & 2.07 & -13.0 & \\
$\mathrm{Pt} / \mathrm{Rb}-\mathrm{Y}$ & $\mathrm{Pt}$ & 7.1 & 6.1 & 2.72 & 1.9 & 1.37 \\
& $\mathrm{O}$ & 0.4 & 5.6 & 2.00 & -12.0 & \\
$\mathrm{Pt} / \mathrm{Cs}-\mathrm{Y}$ & $\mathrm{Pt}$ & 6.6 & 3.8 & 2.74 & 2.2 & 2.26 \\
& $\mathrm{O}$ & 0.5 & 1.4 & 2.05 & -12.0 & \\
$\mathrm{Pt} / \mathrm{Mg}-\mathrm{Y}$ & $\mathrm{Pt}$ & 5.8 & 6.1 & 2.73 & 2.0 & 1.95 \\
& $\mathrm{O}$ & 0.4 & 1.0 & 2.19 & -10.3 & \\
$\mathrm{Pt} / \mathrm{Ca}-\mathrm{Y}$ & $\mathrm{Pt}$ & 6.7 & 5.1 & 2.74 & 2.5 & 1.25 \\
& $\mathrm{O}$ & 0.3 & 5.3 & 2.03 & -13.0 & \\
$\mathrm{Pt} / \mathrm{Sr}-\mathrm{Y}$ & $\mathrm{Pt}$ & 5.1 & 3.1 & 2.74 & 1.9 & 1.30 \\
& $\mathrm{O}$ & 0.5 & 1.3 & 2.10 & -12.0 & \\
$\mathrm{Pt} / \mathrm{Ba}-\mathrm{Y}$ & $\mathrm{Pt}$ & 5.1 & 4.7 & 2.73 & 2.7 & 1.16 \\
& $\mathrm{O}$ & 0.4 & 2.1 & 2.09 & -13.0 &
\end{tabular}

\section{Results and Discussion}

1. Catalyst Characterization. Table 1 summarizes some physicochemical properties of the materials under study as obtained with $\mathrm{N}_{2}$ and $\mathrm{H}_{2}$ physisorption, $\mathrm{NH}_{3}$ TPD, and XRF. The surface area and pore volume of the Pt catalysts are typical for zeolite Y. Neither the surface area, nor the pore volume of the zeolite support is significantly affected by the introduction of Pt nanoparticles in the micropores of zeolite Y. An exception is the $\mathrm{Pt} / \mathrm{Cs}-\mathrm{Y}$ sample, which shows a decreased surface area and pore volume. A possible explanation could be pore blocking by $\mathrm{Pt}$ particles at the outer surface of the zeolite crystals or zeolite destruction due to extensive Pt particle growth. ${ }^{31}$ The Pt content of the different catalysts as determined by XRF varied between $0.7(\mathrm{Pt} / \mathrm{Cs}-\mathrm{Y})$ and $1.3(\mathrm{Pt} / \mathrm{Mg}-\mathrm{Y})$ wt \% Pt, but most of the Pt loadings are close to the target value of $1 \mathrm{wt} \%$. The $\mathrm{H}_{2}$ chemisorption results indicate that the Pt nanoparticles are well-dispersed, although $\mathrm{Pt} / \mathrm{Cs}-\mathrm{Y}$ shows the lowest Pt dispersion, an observation in line with the $\mathrm{N}_{2}$ chemisorption data. Finally, $\mathrm{NH}_{3}$ TPD was used to estimate the number of acid sites in the Pt-loaded zeolite materials. It was found that with the exception of $\mathrm{Pt} / \mathrm{H}-\mathrm{Y}$ the catalyst materials do not contain substantial amounts of protons. More importantly, we do not see any systematic trend as a function of the introduced promoter cations.

The size and size distribution of the supported Pt nanoparticles have been determined with EXAFS and HRTEM. Whereas EXAFS determines an average number for the Pt size (via the number of Pt scatterers), HRTEM gives insight in the size distribution of the supported Pt nanoparticles.

Table 2 summarizes the results of the EXAFS analysis on all the samples under study. The data show that for most samples a $\mathrm{Pt}-\mathrm{Pt}$ coordination number of around 5.5-6.0 was found, which corresponds to a spherical Pt particle size of around 1 $\mathrm{nm}$, most probably located in the supercage of zeolite Y. The three exceptions to this observation are the $\mathrm{Pt}-\mathrm{Pt}$ coordination number of 6.7 for the $\mathrm{Pt} / \mathrm{Cs}-\mathrm{Y}$ and $\mathrm{Pt} / \mathrm{Ca}-\mathrm{Y}$ samples and the $\mathrm{Pt}-\mathrm{Pt}$ coordination number of 7.1 for the $\mathrm{Pt} / \mathrm{Rb}-\mathrm{Y}$ sample. We did not observe scattering against the introduced co-cations, indicating that there is no direct chemical contact between the Pt nanoparticles and the promoter ions. However, because some of the cations introduced (e.g., $\mathrm{Ba}$ and $\mathrm{Sr}$ ) can be regarded as high $\mathrm{Z}$ elements, such a Pt absorber-Z backscatter pair still may exist, although we did not try to fit the higher shell 


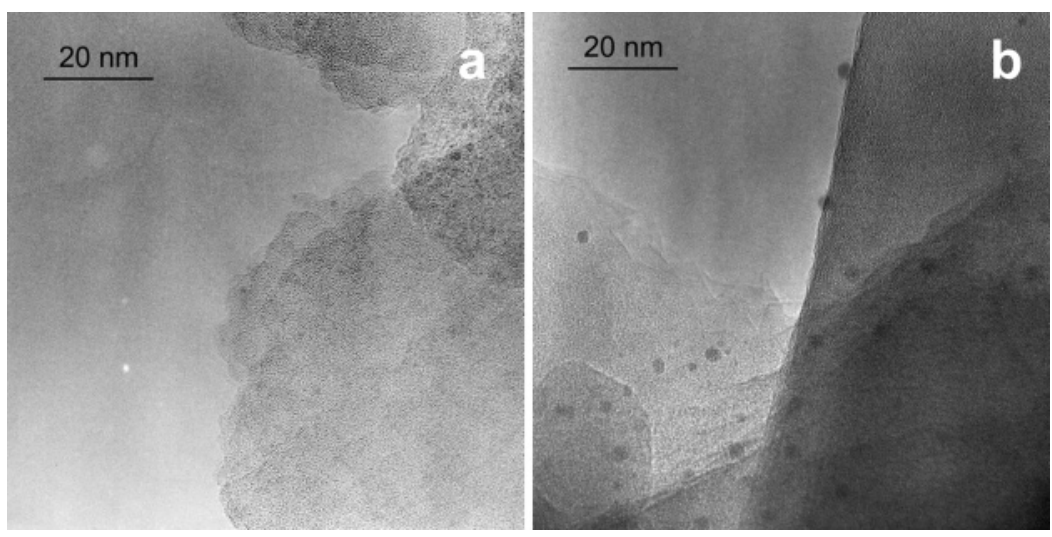

Figure 1. HRTEM micrographs of $\mathrm{Pt} / \mathrm{Na}-\mathrm{Y}$ (a) and $\mathrm{Pt} / \mathrm{Cs}-\mathrm{Y}$ (b) catalyst samples.
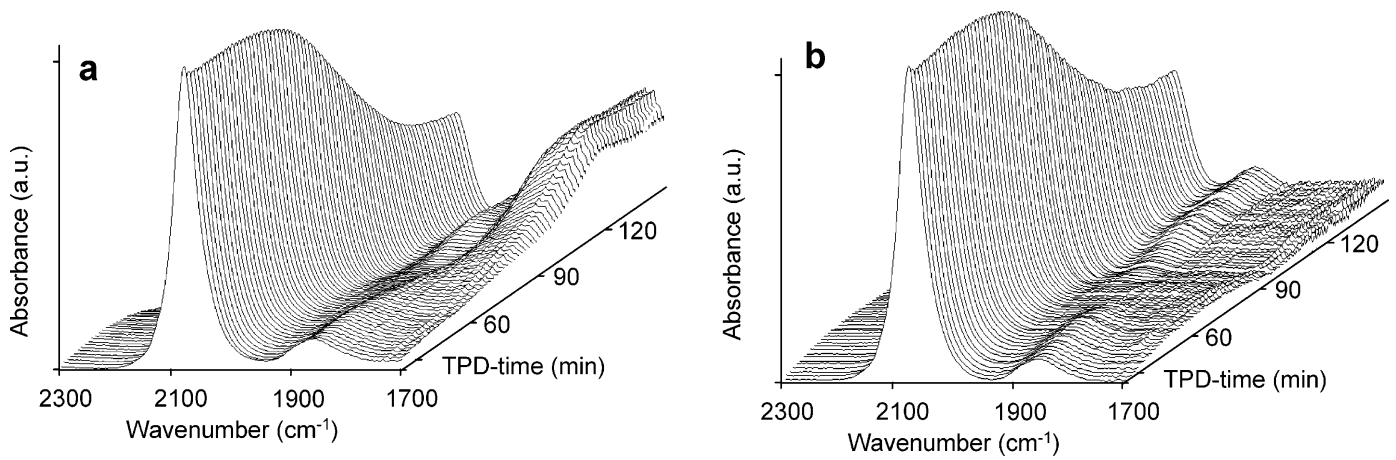

Figure 2. Time-resolved IR spectra during temperature programmed $\mathrm{CO}$ desorption from $\mathrm{Pt} / \mathrm{H}-\mathrm{Y}$ : (a) raw spectra and (b) baseline corrected spectra.

contributions of the EXAFS data. In this respect, it is worthwhile to mention the work of Vaarkamp et al. in which $1.4 \mathrm{Ba}$ atoms were found at a distance of $3.76 \AA$ from a Pt particle with a coordination number of 3.7 in a Pt/BaKL zeolite material. ${ }^{32}$ The small amount of oxygen in the EXAFS fits (Table 2) is a support oxygen originating from the zeolite material. A formal $\mathrm{Pt}-\mathrm{O}$ bond does not exist because the small Pt clusters are reduced in hydrogen. Therefore, an oxygen atom from the support material is the observed scatterer. This results in an increased $\mathrm{Pt}-\mathrm{O}$ bond distance in comparison with platinum oxide. The spread in the $\mathrm{Pt}-\mathrm{O}$ distances is due to the changes induced by the presence of cations as well reflects the affinity of the $\mathrm{Pt}$ particles for the support. Finally, the relative high $E_{0}$ or inner potential values have to be addressed for this scatterer. There is an ongoing discussion on the accepted variance in $E_{0}$ values. The standard, used in the current calculations, is the $\mathrm{Pt}-\mathrm{O}$ bond in $\mathrm{Na}_{2} \mathrm{Pt}(\mathrm{OH})_{6}$. For the type of bond this is the best possible standard, but not fully covering the identity of the zeolite oxygen scatterer, which results in a more then normally accepted variance in $E_{0}$ value.

Figure 1 shows as examples the HRTEM pictures of $\mathrm{Pt} / \mathrm{Na}-\mathrm{Y}$ and $\mathrm{Pt} / \mathrm{Cs}-\mathrm{Y}$. Whereas in the case of $\mathrm{Pt} / \mathrm{Na}-\mathrm{Y}$ no large $\mathrm{Pt}$ nanoparticles can be observed, HRTEM of $\mathrm{Pt} / \mathrm{Cs}-\mathrm{Y}$ shows a significant portion of Pt nanoparticles of $1-5 \mathrm{~nm}$ on top of the zeolite Y crystals. This observation explains, most probably, the decreased surface area and pore volume of this material as well as the higher $\mathrm{Pt}-\mathrm{Pt}$ coordination number. Another explanation could be that the $\mathrm{Pt}$ particles further grow in the $\mathrm{Pt} / \mathrm{Cs}-\mathrm{Y}$ sample exceeding the supercage size, leading to mesopore formation. Evidence for such effects has been reported for the formation of $\mathrm{CDS}$ and $\mathrm{ZnS}$ in $\mathrm{Na}-\mathrm{X}$, Ir clusters in $\mathrm{Na}-\mathrm{X}$ and Pt clusters in ZSM-5 zeolites. ${ }^{31}$ Table 1 summarizes the observations made by HRTEM. It can be concluded that all samples, with the exception of the $\mathrm{Pt} / \mathrm{Cs}-\mathrm{Y}$ matial, contain exclusively or as a main fraction $\mathrm{Pt}$ nanoparticles of $1 \mathrm{~nm}$ or smaller. As expected, the $\mathrm{Pt} / \mathrm{Ca}-\mathrm{Y}$ and $\mathrm{Pt} / \mathrm{Rb}-\mathrm{Y}$ samples contain Pt particles of 3-5 nm as well. Thus, although some differences are noticed between the different samples, EXAFS, $\mathrm{H}_{2}$ chemisorption and HRTEM indicate that well-defined Ptloaded zeolite Y samples have been prepared. These samples contain predominantly $1 \mathrm{~nm}$ Pt nanoparticles, which are most probably occluded in the supercages of zeolite Y.

2. Infrared Spectroscopy. Figures $2-4$ show the time- and temperature-resolved IR spectra of the different supported $\mathrm{Pt}$ catalysts obtained during the CO TPD procedure. It is important to recall that the results of two subsequent measurements of the same self-supported wafer were practically identical, which implies that the samples were not affected by the treatment and that reproducible results were obtained. We also verified the stability of the Pt-zeolite samples during the CO TPD measurements and have noticed with HR-TEM no disintegration or aggregation of the supported Pt nanoparticles. In other words, the applied methodology did not affect the Pt size and size distribution of the $\mathrm{Pt}$ nanoparticles in the different zeolite samples.

Figure 2 shows the CO IR TPD spectra of $\mathrm{Pt} / \mathrm{H}-\mathrm{Y}$. The 3Dset of spectra in Figure 2a are the raw IR data. It is clear that the spectra show a strong IR absorption band at around 2000 $\mathrm{cm}^{-1}$ and a weaker one at around $1800 \mathrm{~cm}^{-1}$. The former band is assigned to the stretching vibration of a linearly Pt-coordinated $\mathrm{CO}$, whereas the latter band is due to bridged $\mathrm{Pt}-\mathrm{CO}$ stretching vibrations..$^{20,33-35}$ Both IR absorption bands decrease in intensity with increasing TPD temperature due to $\mathrm{CO}$ desorption. In addition, a background absorption is arising, which complicates the analysis at higher TPD temperatures. One can apply a baseline correction leading to the spectra shown in Figure $2 b$.

On the basis of Figures 2-4 one can make the following qualitative observations: 

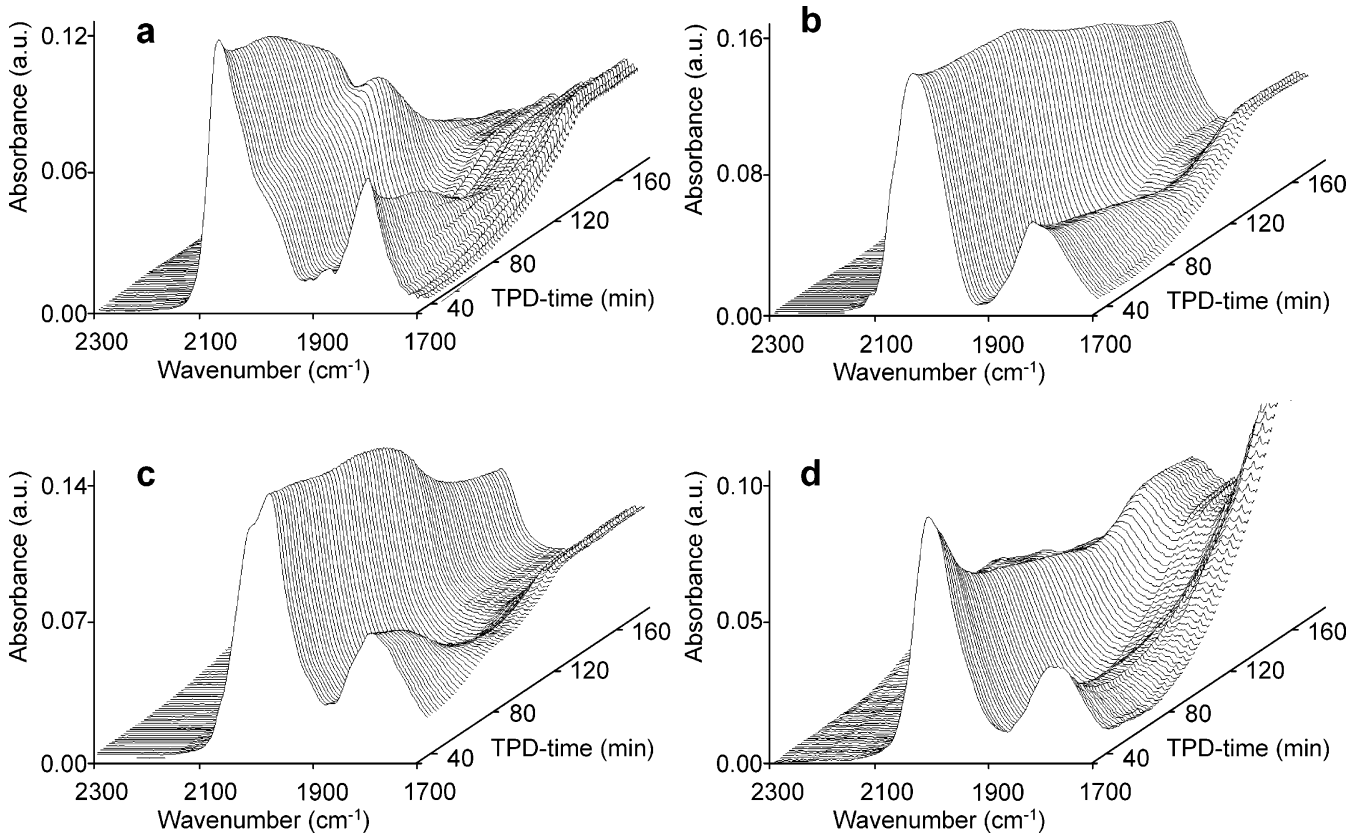

Figure 3. Time-resolved IR spectra during temperature programmed $\mathrm{CO}$ desorption from (a) $\mathrm{Pt} / \mathrm{Na}-\mathrm{Y}$, (b) $\mathrm{Pt} / \mathrm{K}-\mathrm{Y}$, (c) $\mathrm{Pt} / \mathrm{Rb}-\mathrm{Y}$, and (d) $\mathrm{Pt} /$ Cs-Y. No baseline correction has been applied.
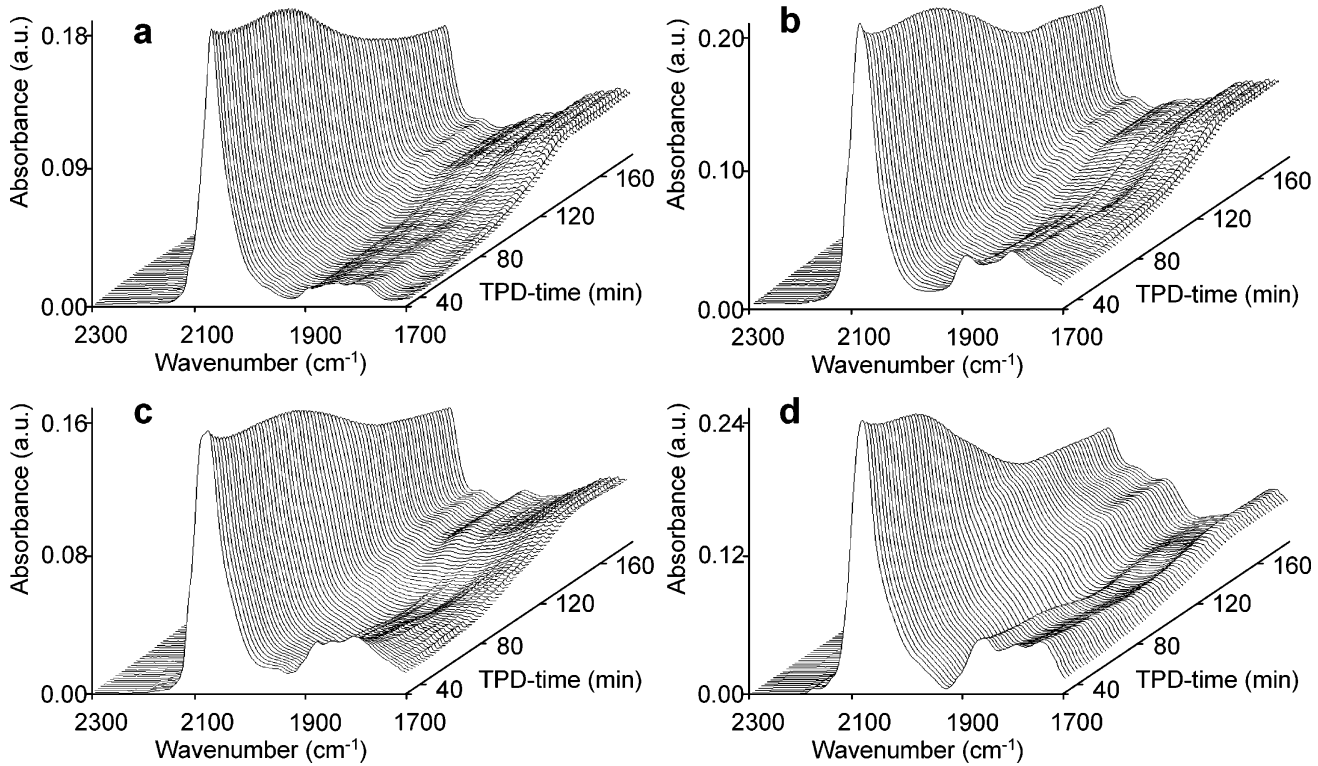

Figure 4. Time-resolved IR spectra during temperature programmed $\mathrm{CO}$ desorption from (a) $\mathrm{Pt} / \mathrm{Mg}-\mathrm{Y}$, (b) $\mathrm{Pt} / \mathrm{Ca}-\mathrm{Y}$, (c) $\mathrm{Pt} / \mathrm{Sr}-\mathrm{Y}$, and (d) $\mathrm{Pt} /$ $\mathrm{Ba}-\mathrm{Y}$. No baseline correction has been applied.

(1) The linear $\mathrm{CO}$ absorption bands of $\mathrm{Pt} / \mathrm{H}-\mathrm{Y}$ (Figure 2) are sharp and symmetrical, whereas alkaline metal (Figure 3) and earth alkaline metal (Figure 4) cation-containing samples possess broad asymmetrical bands with shoulders. Indeed, the bandwidth is small (half bandwidth (HBW) of $49 \mathrm{~cm}^{-1}$ ) for $\mathrm{Pt} / \mathrm{H}-\mathrm{Y}$ compared to those of the alkaline metal cationexchanged (HBW of $90-110 \mathrm{~cm}^{-1}$ ) and the earth alkaline metal cation-exchanged (HBW of 55-70 $\mathrm{cm}^{-1}$ ) zeolite Y samples. In the case of $\mathrm{Pt} / \mathrm{H}-\mathrm{Y}$, the $\mathrm{HBW}$ points to the presence of a single type of linear-coordinated $\mathrm{CO}$ and hence, to a uniform coordination number for the supported Pt particles. ${ }^{33}$ On the other hand, the large HBWs for the cation-containing zeolite $\mathrm{Y}$ samples implies that either different Pt adsorption sites are present or that different $\mathrm{CO}$ orientations are possible as a result of local interactions within the zeolite supercage. The former is rather unlikely, because the Pt particle sizes are practically the same for all the samples, with the exception of $\mathrm{Pt} / \mathrm{Cs}-\mathrm{Y}$
(Table 1 and Figure 1). The most plausible explanation is to assume the presence of nonbonding electrostatic interactions. Two types of nonbonding interaction of the CO-oxygen can affect the $\mathrm{CO}$ vibration and result in different $\mathrm{CO}$ orientations: (a) a repulsive electrostatic interaction with oxygen atoms of the framework ${ }^{36,37}$ and (2) an attractive ion-dipole interaction with framework cations. ${ }^{7}$ Compared to the $\mathrm{Pt} / \mathrm{H}-\mathrm{Y}$ sample, the presence of cations seems crucial in the band broadening effect and so it is most likely that the attractive ion-dipole interactions play the largest role. Next, the presence of cation-affected and "free" CO positions explains to some extent the complex linear $\mathrm{CO}$ band in the IR. In addition, reorientation of $\mathrm{CO}$ as a result of changing interactions might explain the increasing band complexity at higher temperature. This phenomenon is particularly visible in the IR-CO-TPD pattern of $\mathrm{Pt} / \mathrm{Na}-\mathrm{Y}$ by the increasing intensity of the shoulder at $2000 \mathrm{~cm}^{-1}$ upon heating. 
TABLE 3: Positions $\left(\mathrm{cm}^{-1}\right)$ of the Absorption Bands of Linearly and Bridged Pt-Coordinated CO for the Supported Pt Catalysts Measured at Different Temperatures

\begin{tabular}{|c|c|c|c|c|c|c|c|c|}
\hline \multirow[b]{2}{*}{ sample } & \multicolumn{4}{|c|}{$\begin{array}{l}\text { linear Pt-coordinated } \\
\mathrm{C} \equiv \mathrm{O} \text { stretching band }\end{array}$} & \multicolumn{4}{|c|}{$\begin{array}{l}\text { bridged Pt-coordinated } \\
=\mathrm{C}=\mathrm{O} \text { stretching band }\end{array}$} \\
\hline & $323 \mathrm{~K}$ & $373 \mathrm{~K}$ & $473 \mathrm{~K}$ & $573 \mathrm{~K}$ & $323 \mathrm{~K}$ & $373 \mathrm{~K}$ & $473 \mathrm{~K}$ & $573 \mathrm{~K}$ \\
\hline $\mathrm{Pt} / \mathrm{H}-\mathrm{Y}$ & 2083 & 2078 & 2072 & 2066 & 1856 & 1854 & 1751 & 1750 \\
\hline $\mathrm{Pt} / \mathrm{Na}-\mathrm{Y}$ & 2073 & 2036 & 1995 & 1957 & 1823 & 1806 & 1775 & 1720 \\
\hline $\mathrm{Pt} / \mathrm{K}-\mathrm{Y}$ & 2045 & 2022 & 1996 & 1964 & 1821 & 1797 & 1736 & 1723 \\
\hline $\mathrm{Pt} / \mathrm{Rb}-\mathrm{Y}$ & 1992 & 1984 & 1971 & 1963 & 1803 & 1792 & 1725 & 1718 \\
\hline $\mathrm{Pt} / \mathrm{Cs}-\mathrm{Y}$ & 2001 & 1959 & 1937 & 1918 & 1813 & 1753 & 1720 & 1719 \\
\hline \multirow[t]{3}{*}{$\mathrm{Pt} / \mathrm{Mg}-\mathrm{Y}$} & 2087 & 2075 & 2066 & 2054 & 1892 & & & \\
\hline & & & & & 1837 & 1855 & 1855 & \\
\hline & & & & & 1808 & 1786 & 1784 & \\
\hline \multirow[t]{3}{*}{$\mathrm{Pt} / \mathrm{Ca}-\mathrm{Y}$} & 2093 & 2083 & 2069 & 2047 & 1887 & & & \\
\hline & & & & & & 1855 & 1855 & \\
\hline & & & & & 1798 & 1786 & & \\
\hline \multirow[t]{3}{*}{$\mathrm{Pt} / \mathrm{Sr}-\mathrm{Y}$} & 2076 & 2070 & 2059 & 2041 & 1872 & 1868 & 1868 & 1897 \\
\hline & & & & & 1844 & 1845 & 1845 & \\
\hline & & & & & 1802 & 1773 & & \\
\hline \multirow[t]{3}{*}{$\mathrm{Pt} / \mathrm{Ba}-\mathrm{Y}$} & 2076 & 2049 & 2026 & 2021 & 1845 & 1843 & 1834 & 1813 \\
\hline & & & & & 1788 & 1785 & & \\
\hline & & & & & 1760 & 1754 & 1728 & 1723 \\
\hline
\end{tabular}

(2) The differences and shifts of the band maxima for both linear and bridged Pt-coordinated CO for the different samples upon TPD are summarized in Table 3. Comparison of the linear Pt-coordinated CO stretching band position under experimental conditions demonstrates that the maximum decreases upon substitution of the framework protons by alkali or earth alkali metal ions more or less in the same order as their position in the periodic system, i.e., $\mathrm{H}>\mathrm{Na}>\mathrm{K}>\mathrm{Rb} \approx \mathrm{Cs}$ and $\mathrm{Mg} \approx$ $\mathrm{Ca}>\mathrm{Sr}>\mathrm{Ba}$. Similar trends can be observed for the bridged Pt-coordinated CO stretching band. Besides, the spread of about $100 \mathrm{~cm}^{-1}$ for alkali metal cation-containing samples and of about $20 \mathrm{~cm}^{-1}$ for alkaline earth metal cation-containing samples indicates a large difference in the $\mathrm{CO}$ bond strength. These results point to a correlation of the $\mathrm{v}_{\mathrm{C}} \equiv \mathrm{O}$ with the electronic properties of $\mathrm{M}^{+} / \mathrm{M}^{2+}$. Assuming an inversely proportional relationship of $\mathrm{v}_{\mathrm{C}} \equiv \mathrm{O}$ and the $\mathrm{Pt}-\mathrm{C}(\mathrm{O})$ bond strength, one would expect an order in the CO-desorption rate of $\mathrm{Pt} / \mathrm{Cs}-\mathrm{Y}>$ $\mathrm{Pt} / \mathrm{Rb}-\mathrm{Y}>\mathrm{Pt} / \mathrm{K}-\mathrm{Y}>\mathrm{Pt} / \mathrm{Na}-\mathrm{Y}>\mathrm{Pt} / \mathrm{H}-\mathrm{Y}$. A closer examination of the IR-desorption patterns in 3D-projection (Figures 3 and 4) does not show such trend, indicating that there is no simple correlation between the $\mathrm{v}_{\mathrm{C}} \equiv \mathrm{O}$ with the $\mathrm{Pt}-\mathrm{C}(\mathrm{O})$ bond strength. Apparently, a high $\mathrm{CO}$ stretching frequency is not by definition related to a weak $\mathrm{Pt}-\mathrm{C}(\mathrm{O})$ bonding an vice versa. This is in line with a recent conclusion of Wasileski et al. that there is no simple correlation between the field dependent $\mathrm{Pt}$ bonded $\mathrm{CO}$ vibrational frequency and the $\mathrm{Pt}-\mathrm{C}(\mathrm{O})$ bonding energy. ${ }^{38}$

(3) Both alkaline and earth alkaline metal ion-containing samples possess a complex bridged Pt-coordinated CO stretching band pattern and at least three broad and ill-resolved absorption bands are observed (Table 3). This is the most evident for materials loaded with the divalent cations. As can be seen from Figure 4, the intensity decrease of the bridged bonded CO band at around $1800 \mathrm{~cm}^{-1}$ is partially offset by an increase of the baseline and in principle the latter might also be due to the formation of 3- or 4-fold-coordinated $\mathrm{CO}$. However, upon cooling, the baseline decreases to its initial values whereas the linear and 2-fold-coordinated bands do not increase in intensity. For that reason, we reject the formation of the latter type of $\mathrm{Pt}$ bonded CO. It implies that the intensity of the bridged band decreases faster than that of the linear $\mathrm{Pt}-\mathrm{C} \equiv \mathrm{O}$ band at around $2000 \mathrm{~cm}^{-1}$. Comparison among Figures $2-4$ also indicate that the IR band intensities of linear and bridged Pt-coordinated CO decrease with increasing measurement temperature and the

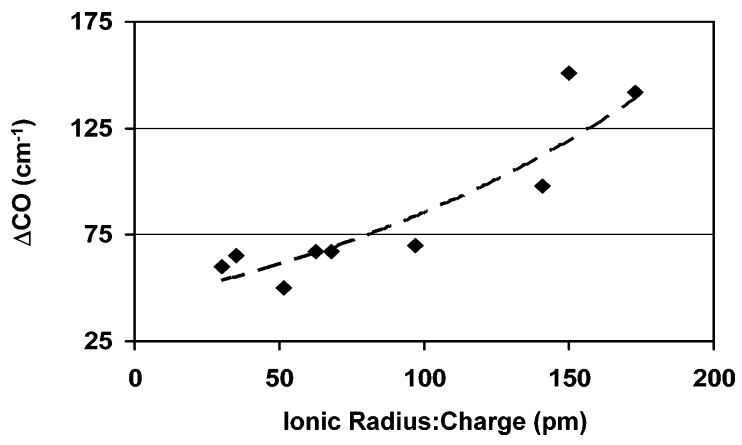

Figure 5. Red shift of linearly bonded $\mathrm{C} \equiv \mathrm{O}$ on supported $\mathrm{Pt}$ nanoparticles compared to gas-phase $\mathrm{C} \equiv \mathrm{O}$ as a function of the promotor cation radius-to-charge ratio. No baseline correction has been applied.

TABLE 4: Overview of the Infrared L:B Ratios and Catalytic Activity Data of the Supported Pt Catalysts under Study $^{a}$

\begin{tabular}{lccc}
\hline sample & $\begin{array}{c}\text { infrared L:B ratio } \\
\text { at } 323 \mathrm{~K}\end{array}$ & $\begin{array}{c}T_{50 \%}(\mathrm{~K}) \text { for } \\
\text { CO conversion }\end{array}$ & $\begin{array}{c}E_{\text {act }}(\mathrm{kJ} / \mathrm{mol}) \text { for } \\
\text { CO conversion }\end{array}$ \\
\hline $\mathrm{Pt} / \mathrm{H}-\mathrm{Y}$ & 10.0 & 460 & 92 \\
$\mathrm{Pt} / \mathrm{Na}-\mathrm{Y}$ & 2.9 & 410 & 92 \\
$\mathrm{Pt} / \mathrm{K}-\mathrm{Y}$ & 2.7 & 390 & 93 \\
$\mathrm{Pt} / \mathrm{Rb}-\mathrm{Y}$ & 2.8 & 405 & 97 \\
$\mathrm{Pt} / \mathrm{Cs}-\mathrm{Y}$ & 2.8 & 355 & 98 \\
$\mathrm{Pt} / \mathrm{Mg}-\mathrm{Y}$ & 8.0 & 450 & 94 \\
$\mathrm{Pt} / \mathrm{Ca}-\mathrm{Y}$ & 4.5 & 420 & 94 \\
$\mathrm{Pt} / \mathrm{Sr}-\mathrm{Y}$ & 4.0 & 395 & 85 \\
$\mathrm{Pt} / \mathrm{Ba}-\mathrm{Y}$ & 3.5 & 420 & 79
\end{tabular}

${ }^{a}$ The L:B ratios have been obtained from the IR spectra after baseline correction.

relative extent of the band intensity decrease is influenced by the presence of alkaline and earth alkaline metal cations. Furthermore, the ratio of the IR band intensities of linear to bridged $\mathrm{Pt}$-coordinated $\mathrm{CO}$ decreases in the order: $\mathrm{Pt} / \mathrm{H}-\mathrm{Y}>$ $\mathrm{Pt} / \mathrm{M}^{2+}-\mathrm{Y}>\mathrm{Pt} / \mathrm{M}^{+-} \mathrm{Y}$.

In what follows, we will elaborate on these differences and present a more quantitative comparison between the materials under investigation. For this purpose, the summed integrated intensities of linear and bridged $\mathrm{Pt}$-coordinated $\mathrm{C} \equiv \mathrm{O}$ stretching bands have been used after normalizing for the Pt contents of the self-supported wafers. Figure 5 relates the red shift of linearly Pt-coordinated $\mathrm{C} \equiv \mathrm{O}$ compared to gas-phase $\mathrm{C} \equiv \mathrm{O}$ (positioned at $2143 \mathrm{~cm}^{-1}$ ) with the cation radius-to-charge ratio of the different cations under study. It is evident that there exists a correlation and a high red shift corresponds to a high cation radius-to-charge ratio. Similar trends are observed for the bridged Pt-coordinated $\mathrm{C} \equiv \mathrm{O}$ stretching band, although due to the complexity and broadness of these bands less straightforward conclusions can be drawn.

Next, the effect of the different co-cations on the intensity ratio of the linear $(\mathrm{L})$ to bridge $(\mathrm{B})$ coordinated bands was examined, and the results are summarized in Table 4. These values were obtained from the IR TPD spectra obtained at 323 $\mathrm{K}$ after baseline correction. Comparison of the IR L:B intensity ratios of the spectra recorded at $323 \mathrm{~K}$ reveal much lower L:B values of 2.7-2.9 for the alkali ion-exchanged Pt-zeolites compared to 10 for the $\mathrm{Pt} / \mathrm{H}-\mathrm{Y}$ sample. Earth alkaline ionexchanged Pt-zeolites have intermediate L:B values of 3.58.0, but importantly, the values follow the trend expected from the ordering in the periodic table. It should be noted that the inaccuracy of the $\mathrm{L}: \mathrm{B}$ values of the $\mathrm{Pt} / \mathrm{M}^{+}-\mathrm{Y}$ and $\mathrm{Pt} / \mathrm{M}^{2+} / \mathrm{Y}$ catalysts is larger than for $\mathrm{Pt} / \mathrm{H}-\mathrm{Y}$ due to the asymmetry of the bands, but the trends remain clear. In addition, we could not find a simple relationship between the red shift for linear 


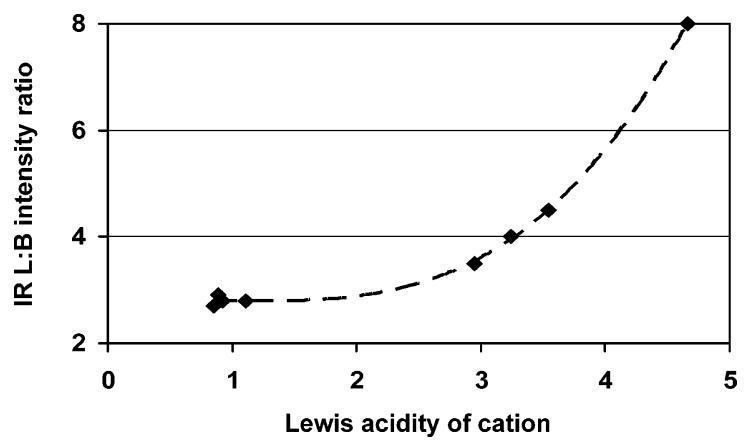

Figure 6. Relationship between IR L:B intensity ratios and Lewis acid properties of the cations introduced in zeolite $\mathrm{Y}$ as expressed by the Kamlet-Taft parameter $\alpha$. The $\mathrm{Pt} / \mathrm{H}-\mathrm{Y}$ sample could not be introduced in this plot because no $\alpha$-values for $\mathrm{H}^{+}$are available.

bonded $\mathrm{C} \equiv \mathrm{O}$ to $\mathrm{Pt}$ and the IR L:B intensity ratio. Instead, we found a relationship between the L:B intensity ratios and the Lewis acid properties of the cations introduced in zeolite Y. The results are summarized in Figure 6. A parameter, describing the Lewis acid behavior of the cations under investigation, is the Kamlet-Taft parameter $\alpha .{ }^{39}$ This parameter expresses the ability of a cation to accept an electron pair and a high $\alpha$ value corresponds with a strong Lewis acid character. It is clear that a weak Lewis acid, such as $\mathrm{K}^{+}(\alpha=0.85)$, results in an increasing electron charge on the framework oxygen atoms and therefore an increasing electron charge on the supported $\mathrm{Pt}$ nanoparticles. This increase results in an increasing occupancy of the d-levels, resulting in an increase in back-donation in the molecular orbital with $2 \pi^{*}$ character and therefore an increasing red shift of the linear $\mathrm{C} \equiv \mathrm{O}$ band and a decreasing infrared $\mathrm{L}: \mathrm{B}$ ratio. The reverse situation can be rationalized for a strong Lewis acid site, such as $\mathrm{Mg}^{2+}(\alpha=4.66)$.

Finally, one can use the integrated band intensities of the linearly and bridged Pt-coordinated $\mathrm{CO}$ molecules to determine the surface coverage of these species as a function of the desorption temperature in the different supported Pt nanoparticles. The obvious assumptions are that (1) the extinction coefficients of linearly and bridged Pt-coordinated $\mathrm{C} \equiv \mathrm{O}$ molecules do not change with increasing desorption temperature, (2) the CO surface coverage does not effect too much the CO band intensities, and (3) the extinction coefficients are not affected to a great extent by the electron properties of the supported Pt nanoparticle. The second assumption is only valid if Pt nanoparticles of similar size and shape are under study, which is the case on the basis of our EXAFS and HRTEM data, with the exception of $\mathrm{Pt} / \mathrm{Cs}-\mathrm{Y}$. With respect to the third assumption, it should be mentioned that extinction coefficients of a carbonyl function ( $\mathrm{C}=\mathrm{O}$ unit comparable to $\mathrm{C} \equiv \mathrm{O}$ ) in aldehydes and ketones are not dramatically altered when the surrounding $\mathrm{R}$ groups are changed. Examples are the molecules $\mathrm{CH}_{3} \mathrm{C}(=\mathrm{O}) \mathrm{CH}_{3}\left(\epsilon=8.5 \mathrm{l} / \mathrm{mol} \cdot \mathrm{cm}^{2}\right)$ and $\mathrm{ClCH}_{2} \mathrm{C}(=\mathrm{O}) \mathrm{C}_{6} \mathrm{H}_{5}(\epsilon$ $\left.=7.9 \mathrm{l} / \mathrm{mol} \cdot \mathrm{cm}^{2}\right) \cdot{ }^{40} \mathrm{In}$ other words, changes in the electron properties of the supported Pt particle due to the presence of a different promoter element are only expected to slightly influence the extinction coefficient of an adsorbed $\mathrm{CO}$ molecule. In a future study we will attempt to determine the extinction coefficients of adsorbed CO on supported Pt nanoparticles.

Figure 7 illustrates the $\mathrm{CO}$ surface coverage for $\mathrm{Pt} / \mathrm{K}-\mathrm{Y}, \mathrm{Pt} /$ $\mathrm{Ca}-\mathrm{Y}, \mathrm{Pt} / \mathrm{Mg}-\mathrm{Y}$, and $\mathrm{Pt} / \mathrm{H}-\mathrm{Y}$ zeolites as a function of the desorption temperature. The values have been obtained by taking into account the weight and Pt content of the IR wafers for each sample as well as by assuming that the extinction coefficient of linearly Pt-coordinated $\mathrm{C} \equiv \mathrm{O}$ molecules is twice as large as that of the bridged $\mathrm{Pt}$-coordinated $\mathrm{C} \equiv \mathrm{O}$ molecules.

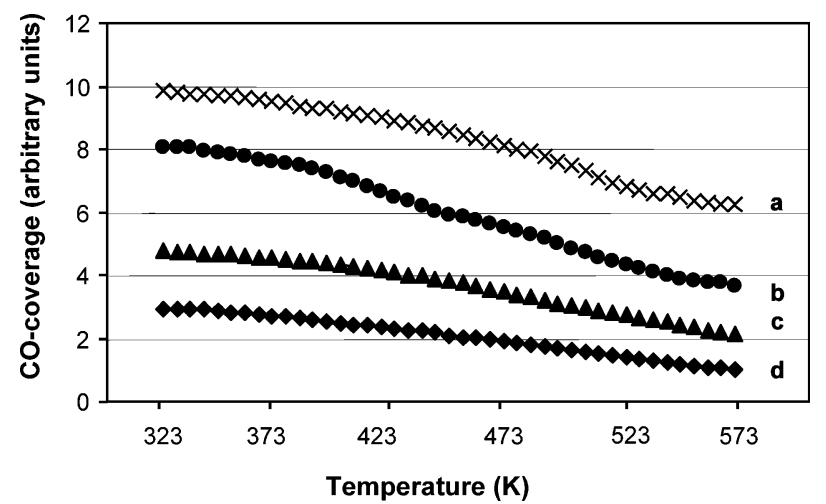

Figure 7. CO coverage on supported $\mathrm{Pt}$ nanoparticles as a function of the desorption temperature: (a) $\mathrm{Pt} / \mathrm{K}-\mathrm{Y}$, (b) $\mathrm{Pt} / \mathrm{Ca}-\mathrm{Y}$, (c) $\mathrm{Pt} / \mathrm{Mg}-\mathrm{Y}$, and $(\mathrm{d}) \mathrm{Pt} / \mathrm{H}-\mathrm{Y}$.

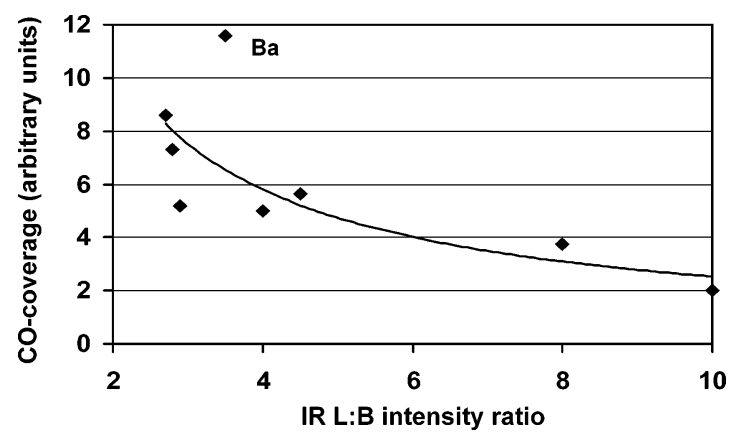

Figure 8. CO coverage on supported $\mathrm{Pt}$ nanoparticles measured at $450 \mathrm{~K}$ as a function of the IR L:B intensity ratio. The $\mathrm{Pt} / \mathrm{Ba}-\mathrm{Y}$ sample behaves atypically and has a very high $\mathrm{CO}$ coverage.

The latter assumption has been obtained from the work of Vannice and Twu. ${ }^{41}$ Figure 7 shows that in each zeolite sample the CO coverage on the supported Pt particles decreases with increasing desorption temperature. In addition, the relative amount of adsorbed $\mathrm{CO}$ is the highest on $\mathrm{Pt} / \mathrm{K}-\mathrm{Y}$ and the lowest on $\mathrm{Pt} / \mathrm{H}-\mathrm{Y}$, whereas the two other Pt-loaded zeolites have intermediate $\mathrm{CO}$ coverages. To elaborate further on this point, we have plotted the $\mathrm{CO}$ coverage values at $450 \mathrm{~K}$ as a function of the corresponding IR L:B ratios of the different samples. The result is illustrated in Figure 8 . It seems that the $\mathrm{CO}$ coverages on supported Pt nanoparticles increase with decreasing IR L:B ratio. In addition, a decreasing $\mathrm{CO}$ coverage leads to an increasing effect of the electronic charge of the $\mathrm{Pt}$ particles on the red shift of the $\mathrm{C} \equiv \mathrm{O}$ stretching band for each adsorbed $\mathrm{CO}$ molecule. In other words, the $v_{\mathrm{CO}}$ will shift due to an increased $2 \pi^{*}$ back-bonding to lower energy for decreasing CO coverage, which is experimentally observed, as shown in Table 3.

3. Pt AXAFS Measurements. Recently, Koningsberger et al. developed a new tool for obtaining structural information from XAFS data of metal-supported catalysts, such as Pt-loaded zeolites. ${ }^{42,43}$ A previously nonutilized feature called AXAFS has been shown to be highly sensitive to the composition of the support oxide. The change in intensity of the Fourier transformed AXAFS peak can be directly related to a change in the interatomic potential of the Pt atoms averaged over the whole Pt metal particle. The change in interatomic potential is caused by an increase or decrease in electron charge (more or less electron-rich) of the support oxygen atoms. The electron charge of the support oxygen atoms in turn is determined by the Madelung potential of the support oxide, which depends on the composition of the support material. Thus, a high intensity of the AXAFS contribution corresponds to an electron-poor $\mathrm{Pt}$ particle and vice versa. ${ }^{44,45}$ 

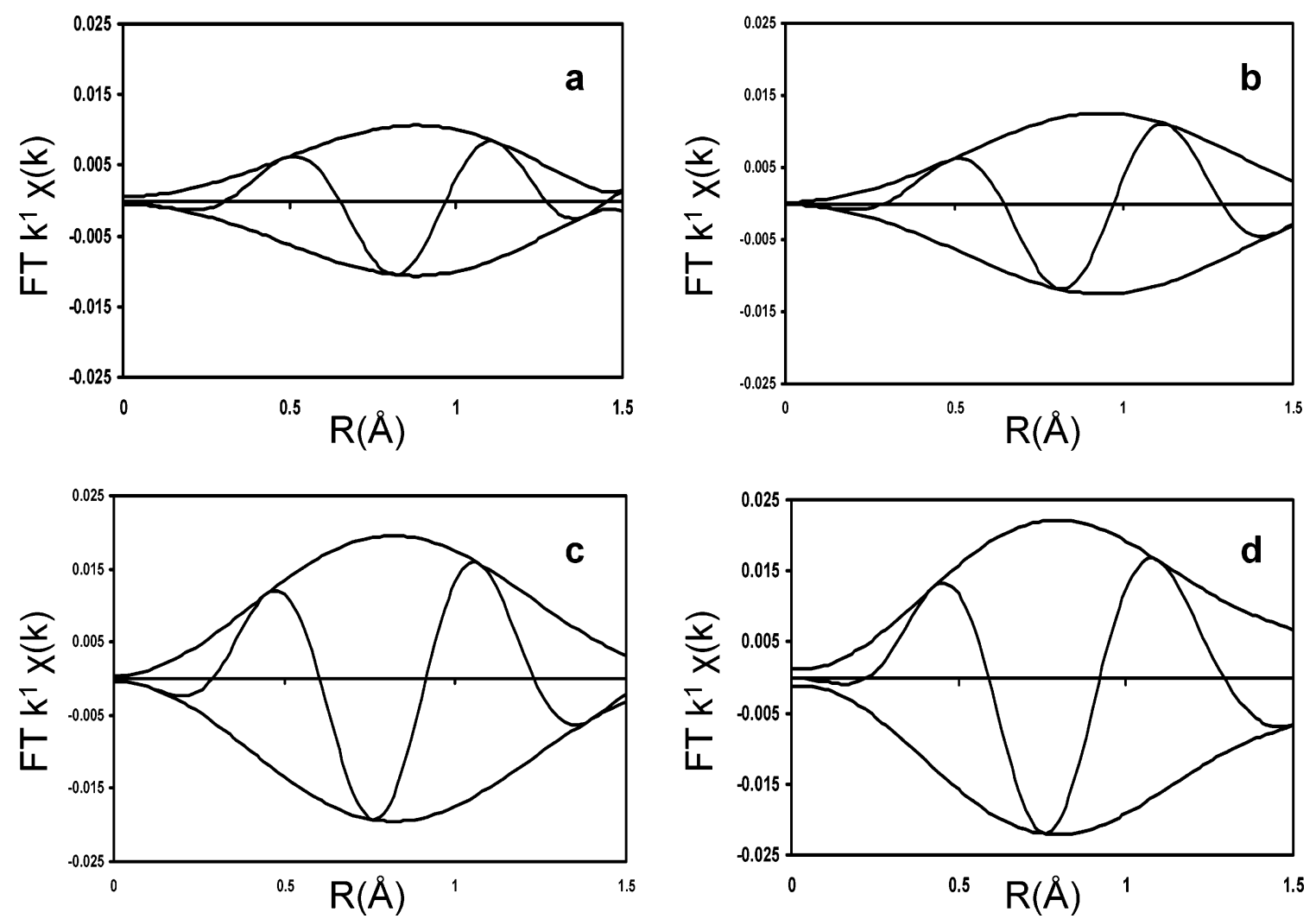

Figure 9. Fourier transform $\left(k^{1}, \Delta k=2.5-8 \AA^{-1}\right.$ ) of atomic XAFS of (a) $\mathrm{Pt} / \mathrm{K}-\mathrm{Y}$, (b) $\mathrm{Pt} / \mathrm{Ca}-\mathrm{Y}$, (c) $\mathrm{Pt} / \mathrm{Mg}-\mathrm{Y}$, and (d) $\mathrm{Pt} / \mathrm{H}-\mathrm{Y}$.

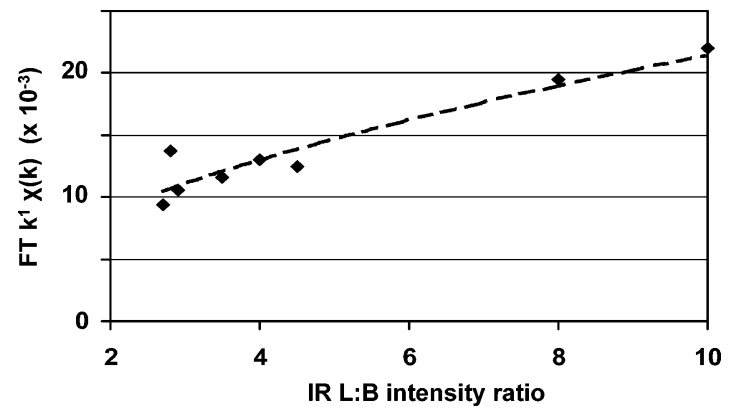

Figure 10. AXAFS peak intensity of supported Pt nanoparticles as a function of the IR L:B intensity ratio.

The AXAFS contribution can be isolated by subtracting the calculated $\mathrm{Pt}-\mathrm{Pt}$ and $\mathrm{Pt}-\mathrm{O}$ contributions from the raw EXAFS data. ${ }^{42}$ Details on the procedure for obtaining AXAFS spectra have been published elsewhere. ${ }^{43}$ Figure 9 shows the AXAFS contributions in the $R$-range from 0 to $1.5 \AA$ for $\mathrm{Pt} / \mathrm{K}-\mathrm{Y}, \mathrm{Pt} /$ $\mathrm{Ca}-\mathrm{Y}, \mathrm{Pt} / \mathrm{Mg}-\mathrm{Y}$, and $\mathrm{Pt} / \mathrm{H}-\mathrm{Y}$ zeolites. One can notice from Figure 9 that the AXAFS data of the different Pt-zeolites differ in their peak intensity, as well as in the peak centroid. A decrease in the AXAFS intensity results in a shift of the peak centroid to higher $R$ values and vice versa. The AXAFS intensities obtained from the XAFS data of the different Pt-zeolites are included in Table 2.

Figure 10 plots the AXAFS peak intensities of the Pt-loaded zeolites versus their corresponding IR L:B ratios and it is evident that the AXAFS intensity decreases with decreasing IR L:B ratio. In other words, both the AXAFS peak intensity and IR $\mathrm{L}: \mathrm{B}$ ratio are measures for the electron charge of the $\mathrm{Pt}$ nanoparticles and as a consequence of the electron charge of the support oxygen atoms. Thus, the AXAFS peak intensity and the IR L:B ratio decreases with increasing electron richness of the $\mathrm{Pt}$ nanoparticles. The $\mathrm{Pt} / \mathrm{H}-\mathrm{Y}$ sample has the highest AXAFS peak intensity as well as the highest IR L:B value,

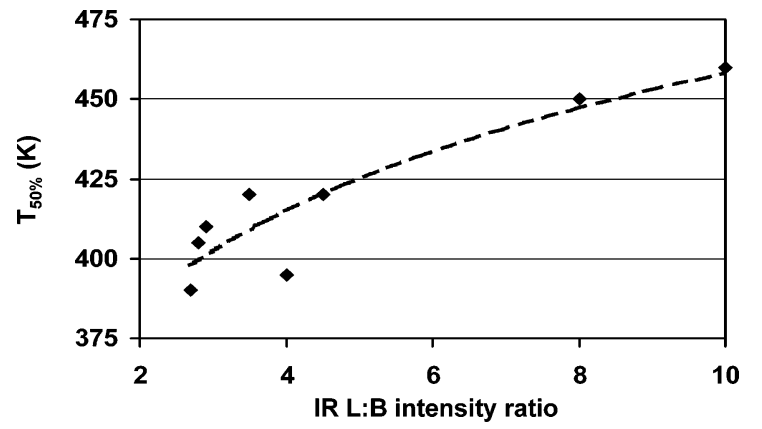

Figure 11. $\mathrm{CO}$ oxidation activity over supported Pt nanoparticles expressed by $T_{50 \%}$ as a function of the IR L:B intensity ratio.

whereas the $\mathrm{Pt} / \mathrm{K}-\mathrm{Y}$ sample has the lowest AXAFS peak intensity and IR L:B value. It is fair to mention that because $\mathrm{Pt} / \mathrm{Cs}-\mathrm{Y}$ contains larger Pt particles, we have not included this data point in Figure 10.

4. CO Oxidation Activity. The supported Pt catalysts under investigation show clearly different catalytic behavior in the oxidation of $\mathrm{CO}$ in the presence of excess oxygen. The temperatures at which $50 \%$ of the $\mathrm{CO}$ is converted $\left(T_{50 \%}\right)$ for the different materials are summarized in Table 4. It is evident that depending on the cation present in the parent zeolite $\mathrm{Y}$ the $T_{50 \%}$ can differ with more than $100 \mathrm{~K}$. The catalytic results can also be plotted as a function of the corresponding IR L:B intensity ratios of the materials, which expresses the electron charge on the supported Pt nanoparticles. The obtained correlation is shown in Figure 11. It is evident that electron-rich supported $\mathrm{Pt}$ nanoparticles promote $\mathrm{CO}$ oxidation activity, whereas electron-poor supported $\mathrm{Pt}$ nanoparticles oxidize $\mathrm{CO}$ at much higher activity. It is important to stress that because the $\mathrm{Pt} / \mathrm{Cs}-\mathrm{Y}$ sample contains larger Pt particles, we have not included this data point in Figure 11; however, the trend remains clear. A more detailed analysis of the catalytic data also revealed 
that the activation energy for $\mathrm{CO}$ conversions between 1 and $10 \%$ was between 79 and $102 \mathrm{~kJ} / \mathrm{mol}$ (Table 4). This is in line with literature data, ${ }^{46}$ indicating that there was no mass transfer limitations in the catalytic systems under study.

$\mathrm{Au}$ : ref 49 was not cited; citation added below to " 47,48 "; relocate as needed

It is well-known that the $\mathrm{CO}$ oxidation on $\mathrm{Pt}$ proceeds via a three-step Langmuir-Hinshelwood reaction scheme:47-49

$$
\begin{gathered}
\mathrm{CO}_{\mathrm{gas}} \leftrightarrow \mathrm{CO}_{\mathrm{ads}} \\
\left(\mathrm{O}_{2}\right)_{\mathrm{gas}} \rightarrow 2 \mathrm{O}_{\mathrm{ads}} \\
\mathrm{CO}_{\mathrm{ads}}+\mathrm{O}_{\mathrm{ads}} \rightarrow\left(\mathrm{CO}_{2}\right)_{\mathrm{gas}}
\end{gathered}
$$

where the indices "gas" and "ads" refer to the gas-phase and adsorbed species, respectively. Under ultrahigh vacuum conditions $\mathrm{CO}$ adsorbs associatively and starts to desorb above about $350 \mathrm{~K}$, whereas $\mathrm{O}_{2}$ adsorbs dissociatively above about $100 \mathrm{~K}$ and desorbs associatively above $720 \mathrm{~K} \cdot{ }^{59,50} \mathrm{CO}$ diffuses rapidly over the surface and reacts with $\mathrm{O}$ to yield $\mathrm{CO}_{2}$, which immediately desorbs into the gas phase. On the basis of the reaction scheme (1)-(3), one can assume that in an excess of oxygen (as is the case for our catalytic experiments) and at temperatures around the desorption temperature of $\mathrm{CO}(350 \mathrm{~K})$, the rate of the reaction $r$ is determined by the relative surface concentration of adsorbed $\mathrm{CO}$, i.e., the $\mathrm{CO}$ surface coverage $\left(\theta_{\mathrm{C} \equiv \mathrm{O}}\right)$. One could then write the reaction equation as follows:

$$
r=-\left\{\mathrm{d}\left[\left(\mathrm{CO}_{2}\right)_{\mathrm{gas}}\right] / \mathrm{d} t\right\}=k^{\prime} \theta_{\mathrm{C} \equiv \mathrm{O}}
$$

As shown before, we were able on the basis of the IR measurements to estimate values for the different catalysts under study. The combined information from Figures 8 and 11 allows us to state that there exists a relationship between $T_{50 \%}$ and $\theta_{\mathrm{C} \equiv \mathrm{O}}$; i.e., $\mathrm{CO}$ oxidation over supported $\mathrm{Pt}$ particles is facilitated by a higher $\mathrm{CO}$ coverage and vice versa. This is in line with reaction eq 4 . This effect can be achieved by adding the adequate promotor element to the catalyst system. $\mathrm{K}^{+}$seems to be the best promoting element for tuning the electronic properties of the supported Pt nanoparticles.

One should, however, be aware that the spectroscopic and catalytic measurements are not done under the same environmental conditions, i.e., reducing vs oxidizing environments. Indeed, the characterization by AXAFS and IR does not necessarily represent the state of the active catalyst material and the reduced Pt particles can be (partially) oxidized under the catalytic conditions employed. An alternative explanation could be that the differences in electron density of the Pt nanoparticles on the different support materials lead to a higher fraction of surface oxidation. An alternative explanation could therefore be that differences in oxygen coverage on the Pt nanoparticles lead to the observed differences in the $\mathrm{CO}$ oxidation performances. In any case, the electronic properties of the supported $\mathrm{Pt}$ nanoparticles influence the catalytic behavior of the materials under study.

Finally, it should be emphasized that the addition of promotor elements has, besides electronic effects, also structural or stabilization effects, which have not been the subject of this work. Much literature exists in which $\mathrm{BaO}$ has been studied in relation to its $\mathrm{NO}_{x}$ storage properties. ${ }^{51-59}$ Here, we show that besides this $\mathrm{NO}_{x}$ adsorption capability, $\mathrm{BaO}$ also induces an electronic effect on the supported $\mathrm{Pt}$ nanoparticles. In this respect, zeolite Y-supported Pt particles of uniform sizes can be regarded as model systems to study in a controlled manner
TABLE 5: Relation between IR, XAFS, and CO Oxidation Results on Supported Pt Catalysts

\begin{tabular}{lllll}
\multicolumn{2}{c}{$\begin{array}{c}\text { properties related to a } \\
\text { specific measuring technique }\end{array}$} & & \multicolumn{2}{c}{ observation } \\
\cline { 1 - 1 } IR & CO L:B ratio & & low & high \\
& CO coverage & & high & low \\
XAFS & AXAFS peak intensity & & low & high \\
& AXAFS peak centroid & & long & short \\
Catalysis & CO oxidation activity & & high & low
\end{tabular}

the effect of the addition of alkaline and alkaline earth metal cations to the electronic properties of Pt. An interesting question remains if the same trends can be obtained for other support types and compositions as well and further work should be directed to reveal such trends and hopefully design more active catalyst systems for car exhaust applications.

\section{Conclusions}

Table 5 relates the different observations obtained by the $\mathrm{CO}$ adsorption infrared, XAFS, and CO oxidation experiments. On the basis of this work the following conclusions can be made:

(1) Time-resolved infrared spectroscopy proves to be a feasible tool to monitor desorption of $\mathrm{CO}$ from supported highly dispersed Pt catalysts as a function of temperature and time. Next to the surface coverage, the position and shape of the linear and bridge $\mathrm{Pt}$ bonded $\mathrm{CO}$ stretching band appear to be very sensitive to the chemical composition of the support and the desorption temperature. The work also demonstrates that a high $\mathrm{CO}$ stretching frequency is not by definition related to the desorption rate of $\mathrm{CO}$, which is not correlated to a strong $\mathrm{Pt}-$ $\mathrm{C} \equiv \mathrm{O}$ bonding and vice versa.

(2) The red shift of the linear Pt-coordinated $\mathrm{C} \equiv \mathrm{O}$ vibration compared to that of gas-phase $\mathrm{CO}$ increases with an increasing cation radius-to-charge ratio. In addition, a systematic shift from linear to bridge bonded $\mathrm{CO}$ was observed for decreasing Lewis acidity, as expressed by the Kamlet-Taft parameter $\alpha$. A decreasing $\alpha$ results in an increasing electron charge on the framework oxygen atoms and therefore an increasing electron charge on the supported Pt nanoparticles.

(3) The CO coverage on the supported Pt nanoparticles increases with increasing electron density on Pt. This increasing electron density was found to result in an increased $\mathrm{CO}$ oxidation activity, and basic promotors facilitate the chemisorption of $\mathrm{CO}$ on the Pt nanoparticles. This adsorbed $\mathrm{CO}$ reacts with adsorbed $\mathrm{O}$ according to a Langmuir-Hinshelwood mechanism to give rise to the formation of $\mathrm{CO}_{2}$. The most promoted $\mathrm{CO}$ oxidation catalyst is a $\mathrm{Pt} / \mathrm{K}-\mathrm{Y}$ sample, which has a $T_{50 \%}$ of $390 \mathrm{~K}$ and a $\mathrm{L}: \mathrm{B}$ ratio of 2.7.

Acknowledgment. This work has been funded by Toyota Motor Research. We kindly thank fruitful discussions with I. Masaru, K. Ishibashi, and S. Matsumoto of Toyota Motor Corporation Japan, Y. Nagai, T. Tanabe, T. Nonaka, H. Sobukawa, and M. Sugiura of Toyota Central R\&D Labs Japan, and O. Kito of the Material Engineering Division of Toyota Motor Europe. P. J. Kooyman (Delft University of Technology) is acknowledged for performing HRTEM measurements, D. C. Koningsberger (Utrecht University) for interesting discussions and help with the EXAFS as well as AXAFS analysis and A. Mens and V. Koot (Utrecht University) for carrying out the $\mathrm{N}_{2}$ and $\mathrm{H}_{2}$ sorption measurements. We also acknowledge beamtime grants from the DUBBLE Grenoble and X1.1 Hasylab beamline stations. 


\section{References and Notes}

(1) (a) Arena, G. E.; Centi, G. Top. Catal. 2004, 30-31, 147. (b) Centi, G.; Arena, G. E. J. Mol. Catal. A Chem. 2003, 204, 663. (c) Fornasari, G.; Trifiro, F.; Vaccari, A.; Prinetto, F.; Ghiotti, G.; Centi, G. Catal. Today 2002, 75, 421. (d) Liotta, L. F.; Macaluso, A.; Arena, G. E.; Livi, M.; Centi, G. Catal. Today 2002, 75, 439.

(2) (a) Schmauke, T.; Eichel, R. A.; Schweiger, A.; Roduner, E. Phys. Chem. Chem. Phys. 2003, 5, 3076. (b) Schmauke, T.; Menzel, M.; Roduner, E. J. Mol. Catal. A Chem. 2003, 194, 211. (c) Zheng, J.; Schmauke, T.; Roduner, E.; Dong, J. L.; Xu, Q. H. J. Mol. Catal. A Chem. 2001, 171 , 181. (d) Schmauke, T.; Moller, E.; Roduner, E. Chem. Commun. 1998, 2589

(3) (a) Miller, J. T.; Koningsberger, D. C. J. Catal. 1996, 162, 209.

(b) Koningsberger, D. C.; Ramaker, D. E.; Miller, J. T.; De Graaf, J.; Mojet, B. L. Top. Catal. 2001, 15, 35. (c) De Graaf, J.; van Dillen, A. J.; de Jong, K. P.; Koningsberger, D. C. J. Catal. 2001, 203, 307.

(4) Barth, R.; Pitchai, R.; Anderson, R. L.; Verykios, X. J. Catal. 1989, 116,61

(5) Blyholder, G. J. J. Phys. Chem. 1968, 60, 2772.

(6) Mojet, B. L.; Miller, J. T.; Koningsberger, D. C. J. Phys. Chem. B 1999, 103, 2724.

(7) Kappers, M. J.; Vaarkamp, M.; Miller, J. T.; Modica, F. S.; Barr, M. K.; van der Maas, J. H.; Koningsberger, D. C. Catal. Lett. 1993, 21 , 235.

(8) Ramaker, D. E.; de Graaf, J.; van Veen, J. A. R.; Koningsberger, D. C. J. Catal. 2001, 203, 7.

(9) Xu, J.; Yates, J. T. Surf. Sci. 1995, 327, 193.

(10) Xu, J.; Hendriksen, P. N.; Yates, J. T. Langmuir 1994, 10, 3663.

(11) Hayden, B. E.; Kretzschmar, K.; Bradshaw, A. M. Surf. Sci. 1985, $149,394$.

(12) Mukerji, R. J.; Bolina, A. S.; Brown, W. A. Surf. Sci. 2003, 527

(13) Barth, A.; Ramachandran, A. J. Catal. 1990, 125, 467.

(14) Gandao, Z.; Coq, B.; de Ménorval, L. C.; Tichit, D. Appl. Catal. A: Gen. 1996, 147, 395.

(15) Bourane, A.; Bianchi, D. J. Catal. 2003, 218, 447.

(16) Welch, P. C.; Mills, P. S. W.; Mason, C.; Hollins, P. J. Electron. Spectrosc. Relat. Phenom. 1993, 64/65, 151.

(17) Hollins, P. Surf. Sci. Rep. 1992, 16, 51.

(18) Koper, M. T. M.; van Santen, R. A.; Wasileski, S. A.; Weaver, M.

J. J. Chem. Phys. 2000, 113, 4392.

(19) Greenler, R. G.; Brandt, R. K. Physicochem. Eng. Aspects 1995, $105,19$.

(20) Hippe, C.; Lamber, R.; Schulz-Ekloff, G.; Schubert, U. Catal. Lett. 1997, 43, 195

(21) Silvestre-Albero, J.; Sepulveda-Escribano, A.; Rodriguez-Reinoso, F.; Anderson, J. A. Phys. Chem. Chem. Phys. 2003, 5, 208. 68 .

(22) Sharma, R. K.; Brown, W. A.; King, D. A. Surf. Sci. 1998, 414,

(23) Stoop, F.; Toolenaar, F. J. C. M.; Ponec, V. J. Catal. 1982, 73, 50.

(24) Geidel, E.; Lechert, H.; Dobler, J.; Jobic, H.; Calazferri, G.; Bauer, F. Micropor. Mesopor. Mater. 2003, 65, 31 .

(25) Otero Arean, C.; Turnes Palomino, G.; Zecchina, A.; Spoto, G.; Bordiga, S.; Roy, P. Phys. Chem. Chem. Phys. 1999, 1, 4139.

(26) De Mallman, A.; Barthomeuf, D. Stud. Surf. Sci. Catal. 1989, 46 429.

(27) Gijzeman, O. L. J.; Mens, A. J. M.; van Lenthe, J. H.; Mortier, W. J.; Weckhuysen, B. M. J. Phys. Chem. B 2003, 107, 678.

(28) Vaarkamp, M.; Linders, J. C.; Koningsberger, D. C. Physica B 1995, 208/209, 9825.

(29) Vaarkamp, M.; Mojet, B. L.; Kappers, M. J.; Miller, J. T. Koningsberger, D. C. J. Phys. Chem. 1995, 99, 16067.
(30) Nijhuis, T. A.; Makkee, M.; van Langeveld, A. D.; Moulijn, J. A. Appl. Catal. A: Gen. 1997, 164, 237.

(31) Schulz-Ekloff, G. Stud. Surf. Sci. Catal. 1991, 69, 65. Wark, M.; Schulz-Ekloff, J. N. I.; Zukal, A. Stud. Surf. Sci. Catal. 1991, 69, 189.

(32) Vaarkamp, M.; Grondelle, J. V.; Miller, J. T.; Sajkowski, D. J.; Modica, F. S.; Lane, G. S.; Gates, B. C.; Koningsberger, D. C. Catal. Lett. 1990, 6, 369 . 5,67

(33) Sheppard, N.; Nguyen, T. T. Adv. Infrared Raman Spectrosc. 1978

(34) Bourane, A.; Dulaurent, O.; Bianchi, D. J. Catal. 2000, 196, 115.

(35) Greenler, R. G.; Brandt, R. K. Colloids Surf. A: Physicochem. Eng. Asp. 1995, 105, 19

(36) Larin, A. V.; Leherte, L.; Vercauteren, D. P. Phys. Chem. Chem. Phys. 2002, 4, 2416.

(37) Larin, A. V.; Vercauteren, D. P.; Lamberti, C.; Bordiga, S.; Zecchina, A. Phys. Chem. Chem. Phys. 2002, 4, 2424.

(38) Wasileski, S. A.; Weaver, M. A.; Koper, M. T. M. J. Electroanal. Chem. 2001, 500, 344

(39) Marcus, Y. Ion properties; Marcel Dekker: New York, Basel, Hong Kong, 1997; p 193.

(40) Renema, J. Structural information from carbonyl stretching frequencies. Ph.D. Thesis, Utrecht University, 1972.

(41) Vannice, M. A.; Twu, C. C. J. Chem. Phys. 1981, 75, 5944.

(42) Koningsberger, D. C.; Mojet, B. L.; van Dorssen, G. E.; Ramaker,

D. E. Top. Catal. 2000, 10, 143

(43) Ramaker, D. E.; van Dorssen, G. E.; Mojet, B. L.; Koningsberger,

D. C. Top. Catal. 2000, 10, 157.

(44) Koningsberger, D. C.; de Graaf, J.; Mojet, B. L.; Ramaker, D. E.;

Miller, J. T. Appl. Catal. A: General 2000, 191, 205.

(45) Mojet, B. L.; Miller, J. T.; Ramaker, D. E.; Koningsberger, D. C. J. Catal. 1999, 186, 373

(46) Venderbosch, R. H.; Prins, W.; van Swaaij, W. P. M. Chem. Eng. Sci. 1998, 53, 3355.

(47) Ertl, G.; Engel, T. Adv. Catal. 1979, 28, 1.

(48) Ertl, G. Adv. Catal. 1990, 37, 1.

(49) Nolan, P. D.; Lutz, B. R.; Tanaka, P. L.; Davis, J. E.; Mullins, C. B. J. Chem. Phys. 1999, 111, 3696.

(50) Artsyukhovich, A. N.; Ukraintsev, V. A.; Harrison, I. Surf. Sci. 1996, 347, 303.

(51) Broqvist, P.; Gronbeck, H.; Fridell, E.; Panas, I. J. Phys. Chem. 2004, 108, 3523 .

(52) Nova, I.; Castoldi, L.; Prinetto, F.; Dal Santo, V.; Lietti, L.; Tronconi, E.; Forzatti, P.; Ghiotti, G.; Psaro, R.; Recchia, S. Top. Catal. 2004, 30-31, 181.

(53) Fridell, E.; Skoglundh, M.; Westerberg, B.; Johansson, S.; Smedler, G. J. Catal. 1999, 183, 196.

(54) Olsson, L.; Persson, H.; Fridell, E.; Skoglundh, M.; Andersson, B. J. Phys. Chem. B 2001, 105, 6895.

(55) Lesage, T.; Verrier, C.; Bazin, P.; Saussey, J.; Daturi, M. Phys. Chem. Chem. Phys. 2003, 5, 4435.

(56) Lesage, T.; Verrier, C.; Bazin, P.; Saussey, J.; Malo, S.; Hedouin, C.; Blanchard, G.; Daturi, M. Top. Catal. 2004, 30-31, 31.

(57) Shinjoh, H.; Tanabe, T.; Sobukawa, H.; Sugiura, M. Top. Catal. 2001, 16-17, 95

(58) Takahashi, N.; Shinjoh, H.; Iijima, T.; Suzuki, T.; Yamazaki, K.; Yokota, K.; Suzuki, H.; Miyoshi, N.; Matsumoto, S.; Tanizawa, T.; Tanaka, T.; Tateishi, S.; Kasahara, K. Catal. Today 1996, 27, 63.

(59) Shinjoh, H.; Takahashi, N.; Yokota, K.; Sugiura, M. Appl. Catal. B Environ. 1998, 15, 189. 